\title{
Influence of Contextual Factors and Continuous Medical Education on Healthcare Outcomes in the Republic of Serbia
}

\author{
Mira H. Vuković \\ Education Center, General Hospital Valjevo, Valjevo, Serbia
}

\section{SUMMARY}

Introduction: The basic purpose of the professional continuing education is facilitating the successful conduct of practitioners in the field of practical characteristics of their professional work.

Topic: In the Republic of Serbia (RS), the current Ordinance on Closer Conditions for Continuing Education for Healthcare Workers and Healthcare Associates implies that there is a connection between continuing medical education (CME) and the improvement of quality of healthcare workers and healthcare associates. However, such connectivity is difficult to prove. In order for the CME programs to be effective in improving the quality of work of healthcare professionals, it is essential that the well-known criteria for assessing the effectiveness of the CME programs be implemented in the Ordinance of the RS.

Conclusions: Strong application of the criteria for assessing the effectiveness of the CME program can lead to improvement of the performance of the healthcare professionals, patient outcomes and the population's health in the RS.

Keywords: medical education, behavior, healthcare professionals, patients outcomes

\section{INTRODUCTION}

In the 1980s, Houle defined the basic purpose of continuing education to "facilitate the success ful conduct of practitioners in the field of the various, practical characteristics of their professional work" [1]. On the other hand, in the Republic of Serbia, the current Ordinance of Closer Conditions for Continuing Education for Health Care Workers and Health Associates defines that "health workers and healthcare workers have the right and duty to constantly monitor the development of medical, dental, pharmaceutical science and other corresponding doctrine, and do advanced training in order to maintain and improve the quality of their work" [2]. Since the distinction is clear between the attempt to define the "purpose" of education and to define the "rights and duties" of healthcare workers, [3] it could be expected that the basically forgotten "purpose" brought up new proposal of the Serbian Medical Council on amendments to the current Ordinance. These "new proposals" contained about ten amendments, which concerned the quality control of the implementa- 
tion of individual continuing medical education (CME) programs [4].

\section{TOPIC}

The proposed amendments included the penal provisions that included Article 20: "If any irregularity is found in the performance of an accredited continuing education program or if there is any discrepancy in the execution of the accredited program, the Health Council shall take a decision on the prohibition of the implementation of accredited continuing education and prohibition of the registration of all new continuing education programs within a period of 12 months from the date of the decision". Thus, in the amendments, the phrase "monitoring and evaluation of the quality of the CME program", actually referred to "monitoring and evaluating the regularity of the CME implementation". Fortunately, the mentioned amendments were not adopted because their adoption could produce a legal absurdity situation that seriously undermines the rights of those who have been granted these rights. On the other hand, without any scientific evidence, the proposed amendments set the premise that the methodology of a simple and easy way "the quality of individual CME programs" can be related to "improving the quality of work" of healthcare workers and healthcare associates. Namely, terms such as "CME quality" and "improvement of work quality" are too general and indefinite, and as such are not commonly applicable in the scientific assessment of the effects or effectiveness of the CME program. The quality assessment of the CME program, above all, must relate to the assessment of the effectiveness of CME in improving the working characteristics of the healthcare workers and healthcare associates. However, the proposed amendments were supposed to rate the $\mathrm{CME}$ on the basis of:

1) the assessment of the quality of the accredited continuing education program (bad, good, very good, excellent, exceptional),

2) the prices of the accredited continuing education program (low, appropriate, high) and

3 ) the organization of accredited continuing education program such as respect of the hours, the adequacy of the space, completeness of the participants' meeting data (appropriate good, very good, excellent or inadequate).

However, according to the latest synthesis of systematic review studies (Carvero and Gaines, 2015), in terms of improving effectiveness, the following strategies should be included in the design of the teaching model, both for planning and evaluation of the CME programs [5]:

A) CME has a more reliable positive impact on the performance of the physician compared to the health outcomes of patients.

B) CME leads to a greater improvement of the physician's performance and the patient outcomes if education is: (1) interactive, (2) uses or combines multiple learning methods, (3) covers multiple exposures, if (4) longer and (5) focused on outcomes that are considered important to the physician.

Unfortunately, in the current Ordinance of the Republic of Serbia, in evaluating and awarding points for accredited CME programs, the length of the education is disproportionately evaluated in relation to the other three criteria mentioned above. Likewise, it is losing sight of the fact that in reviewed studies of the Cochrane group, the term "meeting" (or expert meeting) synchronously refers to a whole group of educations such as: courses, conferences, lectures, workshops, seminars and symposiums and essentially (at least in terms of considering their effectiveness) expert meetings just differ only in terms of length (short - up to 6 hours, medium length - up to one day and longer - for a few days) [6].

The next criteria that should be included in the CME evaluation are certainly the explanation of the proposer (CME organizer) of the chosen evaluation framework, as well as the design of the CME effectiveness assessment. With regard to design, the advantage must have a randomized but also quasi-experimental design. Selection and explanation of the multi-level assessment framework of effectiveness, e.g. Moore's seven-level assessment framework or Kirkpatrick's four-level assessment framework should also take precedence $[7,8]$. Regardless of whether all the levels of assessment of the effectiveness of the CME program are ultimately carried out under the above mentioned frameworks, performing multiple levels of assessment is crucial for better evaluation of training in its application for approval to the competent Chamber and the Serbian Medical Council. More levels of the CME assessment imply serious planning, prior consideration of the context and the need for education [5,8], determination of the motivation of the physician, setting a clear educational goal, target 
group analysis to which the planned activities are addressed, careful planning of activities, choice of tracing of the target characteristics of the physician that education can potentially improve (clinical decision, economic behavior, skills and competence), [9] choice of variables related to patient outcomes, choice and implementation of analytical methods for assessing the CME listening response (e.g. satisfaction and motivation), assessment of declarative and practical knowledge of the listener, patient outcomes important for the physician (clinically - objective or subjectively expressed by the patient), as well as analytical methods for assessing population health.

To give a suggestion in this regard, we are also encouraged by the results of our case study, which showed the high effectiveness of didactic CME in reducing the cost of quality and reducing the irrational use of human albumin solution on the surgical department and reducing the mortality of patients with severe sepsis and septic shock, [10,11] which also studied contextual effects such as the intervention of the Serbian Republican Health Insurance Fund (SRHIF) in determining and changing criteria for prescribing human albumin solutions. Namely, despite the above-mentioned intervention by the SRHIF to achieve certain economic effects during the pre-education period, unlike education interventions, there was no impact of the SRHIF intervention in terms of improving the health outcomes of patients. In our follow-up reports, we have also shown that the accreditation of health institutions in the Republic of Serbia has no impact on the most important health outcomes, such as total hospital mortality or mortality in surgical departments [12].

It is well known that the effects of CME are not immune to the influence of contextual factors (political, economic, social). For CME reform, lack of knowledge is less of a problem, while the greater the problem has political nature, which is reflected in the change of system in which CME should become an important constituent element [13-17].

\section{CONCLUSION}

By adopting the aforementioned additional criteria for assessing the effectiveness of CME, as well as by defining a CME validation strategy, it would be a serious step in reforming the health system of the Republic of Serbia. The existing health system that has so far mainly consumed CME points could potentially become a system that would have a serious intent to consume CME benefits, in accordance with current scientific tendencies in CME improvement [18]. These potential benefits include: (1) improving the performance of the physician, (2) improving patient outcomes, and (3) improving the population's health.

\section{ACKNOWLEDGEMENTS}

We are thankful for linguistic corrections of the manuscript text to Ana Vuković, language and literature professor.

\section{REFERENCES}

1. Houle CO. Continuing Learning in the Professions. San Francisco, CA: Jossey-Bass; 1980.

2. Ordinance on Closer Conditions for the Implementation of Continuous Education for Health Workers and Health Associates - "Official Gazette of RS", No. 2/2011, 23/2016. Available at: http:// www.zdravstvenisavetsrbije.gov.rs/dokumenta/zakoni/PravilnikOBlizimUslovimaZaSprovodenjeKontinuiraneEdukacije.pdf. Accessed August 16, 2017.

3. World Health Organization (2013). Transforming and scaling up health professionals' education and training: World Health Organization guidelines 2013. World Health Organization.

4. Report on the work of the Health Council of Serbia in 2016. Available at: http://www.zdravstvenisavetsrbije.gov.rs/index.php?page $=4$. Accessed August 16, 2017.

5. Cervero RM, Gaines JK. The Impact of CME on Physician Performance and Patient Health Outcomes: An Updated Synthesis of Systematic Reviews. J Contin Educ Health Prof 2015;35(2):131-138.

6. Forsetlund L, Bjorndal A, Rashidian A, Jamtvedt $G$, O'Brien MA, Wolf F, et al. Continuing education meetings and workshops: effects on professional practice and health care outcomes. Cochrane Database Syst Rev 2009(2):CD003030.

7. Moore DE Jr, Green JS, Gallis HA. Achieving desired results and improved outcomes: integrating planning and assessment throughout learning activities. J Contin Educ Health Prof 2009;29(1):1-15.

8. Kirkpatrick DL. Evaluating Training Programs. San Francisco: Berrett-Koehler Publishers 1994, Inc.

9. Jakovljevic M, Vukovic M, Chia-Ching C, Antunovic $M$, Dragojevic- Simic V, Velickovic-Radovanovic R, Siladji Mladenovic Dj, Jankovic N, Rankovic A, Kovacevic A, Antunovic M, Milovanovic O, Markovic V, Babu N.S. D, Yamada T. Do health reforms impact cost consciousness of Health care professionals? Results from a nation-wide survey in the Balkans. Bal- 
kan Medical Journal 2016;33:8-17. DOI: 10.5152/ balkanmedj.2015.15869

10. Vuković $M H$, Gvozdenović BS, Jakovljević $M B$, Živanović PA, Mitrović DM, Plećić IM, Ilić MŽ. Is 28Day Follow-Up Period Enough for Examining the Mortality after Resuscitation with Human Albumin? Hospital Pharmacology. International Multidisciplinary Journal 2014;1(1):1-8.

11. Vuković M, Gvozdenović BS, Ranković M, McCormick BP, Vuković DD, Gvozdenović BD, Kastratović DA, Marković SZ, Ilić M, Jakovljević MB. Can didactic continuing education improve clinical decision making and reduce cost of quality? Evidence from a case study. J Contin Educ Health Prof 2015;35(2):109-118. DOI: 10.1002/chp.21272

12. Marković-Petrović $G$, Vuković $M$, Jović-Vraneš $A$. The impact of accreditation on health care quality in hospitals. Vojnosanitetski pregled 2016; OnLineFirst (00):390-390. DOI: 10.2298/VSP160728390M

13. Cervero RM, Moore DE Jr. The Cease Smoking Today (CS2day) initiative: a guide to pursue the 2010 IOM report vision for CPD. J Contin Educ Health Prof 2011;31(Suppl 1):S76-S82.

14. Balmer JT. The transformation of continuing medical education (CME) in the United States. Adv Med Educ Pract 2013;4:171-182.

15. Jakovljevic MB. Resource allocation strategies in Southeastern European health policy. Eur J Health Econ 2013;14(2):153-159.

16. Jakovljevic M, Jovanovic M, Lazic Z, Jakovljevic V, Djukic A, Velickovic R, Antunovic M. Current efforts and proposals to reduce healthcare costs in Serbia. Ser J Exp Clin Res 2011;12 (4): 161-163.

17. Jakovljevic MB. Health Expenditure Dynamics in Serbia 1995-2012. Hospital Pharmacology - International Multidisciplinary Journal 2014; 1(3):180-183.

18. Altamirano-Bustamante MM, Altamirano-Bustamante N F, Lifshitz A, Mora-Magaña I, de Hoyos A, Ávila-Osorio $M T, \ldots$ \& Nava-Diosdado R. Promoting networks between evidence-based medicine and values-based medicine in continuing medical education. BMC medicine 2013;11(1): 39. 


\section{Uticaj kontekstualnih faktora i kontinuirane medicinske edukacije na zdravsvene ishode u Republici Srbiji}

Mira H. Vukovic

Centar za edukaciju, Zdravstveni centar Valjevo, Valjevo, Srbija

\section{KRATAK SADRŽAJ}

Uvod: Osnovna svrha stručnog kontinuiranog obrazovanja je olakšavanje uspešnog obavljanja rada praktičara u pogledu praktičnih obeležja njihovog profesionalnog rada.

Tema: U Republici Srbiji (RS), sadašnji Pravilnik o bližim uslovima za kontinuiranu edukaciju zdravstvenih radnika i zdravstvenih saradnika podrazumeva povezanost kontinuirane medicinske edukacije (KME) sa poboljšanjem kvaliteta rada zdravstvenih radnika i zdravstvenih saradnika. Međutim, takvu povezanost teško je dokazati. Kako bi programi KME bili učinkoviti u poboljšanju kvalitete rada zdravstvenih stručnjaka, bitno je da se u Pravilniku RS uvedu dobro poznati kriterijumi za procenu učinkovitosti KME programa.

Zaključak: Stroga primena kriterijuma za procenu delotvornosti KME programa može dovesti do poboljšanja učinkovitosti rada zdravstvenih stručnjaka, ishoda pacijenata i zdravlja stanovništva u RS.

Ključne reči: medicina, edukacija, ponašanje, zdravstveni profesionalci, ishodi lečenja 